\title{
Between Women: Indenture, Morality and Health
}

\author{
Margaret Mishra
}

Indentured women in Fiji collectively challenged their exploitation in the sugarcane plantations from the late 1800s to the early 1900s. The primary forum used to articulate their grievances and oppose their maltreatment was the Indian Women's Committee. The activism of this Committee was particularly intense from 1913 to 1920 when its platform intersected with international campaigns in India to abolish the indenture system. During this period, parallel resistances were mounted by the Australasian Committee of Inquiry into the Social and Moral Conditions of Indentured Women in Fiji. This Committee, comprising Australian, New Zealand and Indian women, adopted transnational principles to advance the social and moral position of indentured women in Fiji. While the Committee may be critiqued for furthering patriarchal constructions of morality and femininity that converged with discourses of colonialism, imperialism and Indian nationalism, this article will demonstrate that it simultaneously played a critical role in improving the quality of life for indentured women in Fiji, particularly in the area of women's health.

\section{Situating Women's Resistances during Indenture}

After Fiji's cession to Britain on 10 October 1874, the Governor General of the British colonial government, Sir Arthur Gordon, sought a cheap, external source of labour allegedly to protect and perpetuate the indigenous Fijian way of life in the villages (Lal 4). His solution was to introduce the system of Indian labour recruitment which Indians referred to as girmit. From 1879 to 1919, approximately 13,696 Indian women and 54,784 Indian men were transported to Fiji under this agreement (Lateef 2). At the end of the five year term, labourers could either return to India or renew the contract for an additional five years. Historical accounts suggest that some Indian women came to Fiji to escape from economic hardship, domestic quarrels and oppressive cultural rituals and practices, for example, the dowry system (Lal 57; see also Naidu 19-23). Others were lured or kidnapped by unscrupulous recruiters who promised them an abundant supply of food and relaxed working conditions. Fijian feminist Shireen Lateef confirms the trickery of some recruiters as she relates how her grandmother came to Fiji: 'While my grandmother was getting water from a well, a recruiter 
approached her and asked her whether she would like to go to Fiji, a faraway place where there was good weather, picturesque surroundings, easy work and plenty of food. Without telling anyone, she left with him immediately' (Lateef 2 ). The reality, of course, was quite the opposite. As wage-earners, mothers and wives, Indian women in Fiji were subjected to poor living conditions, physical and sexual violence, long hours of work on the plantations, and wage cuts for low attendance during sickness and pregnancy (Lal 57; see also Andrews 26). Unsurprisingly, these exploitative circumstances, often likened to a form of slavery or narak (hell), triggered a series of militant resistances. Many of these vocal, public, and sometimes violent contestations were led by Indian women.

In the years between the late 1800s and early 1900s, for instance, indentured women workers established a forum called the Indian Women's Committee where they could collectively challenge their multiple oppressions (Mishra 39). Human rights activist Shiasta Shameem narrates how this Committee, colloquially known as 'the Women's Gang', led a series of protests against the physical, sexual and economic exploitation of indentured women in the cane belts of Fiji (274). These resistances arose out of women's marginalised statuses as labourers, mothers and wives. The most common form of resistance involved physically confronting men who sexually violated indentured women and beating them up. Sometimes the punishment entailed pinning the overseer down and taking turns at urinating on him, or walking over him until he excreted (Naidu 19). Indentured women consciously employed, in reverse, the same tactics of violence, humiliation and degradation that they themselves were incessantly exposed to, to lay bare the impact of male violence. This method of resistance not only furthered a mutual dependence among women but also involved drawing indentured men into the 'orbit of plantation resistance' (Shameem 274). In this sense, the activism of indentured women in the early 1900s could not be separated from a partnership with men who shared, to borrow an expression from postcolonial theorists, 'the experience of the politics of oppression and repression' (Ashcroft et al. 250).

The second method of resistance adopted by indentured women involved heading strikes and riots in Suva, Rewa and Navua during the 1920s. During this period, the Indian Women's Committee spoke officially on behalf of female and male labourers. While these protests took place in the public sphere, they often intersected with issues of concern in the private sphere. In 1920, for example, The Fiji Times and Herald reported that the Indian Women's Committee led a deputation to the Governor petitioning for higher wages and an official inquiry into escalating food prices ('Commission to Enquire into the Cost of Living' 7). The official representative for the deputation was Jaikumari Manilal, wife of Fiji's first Indian barrister Dr. Manilal Maganlal. Although Jaikumari, a middle-class Indian woman and satyagarha activist trained at Gandhi's ashram in Gujarat, wrote petitions and organised meetings and demonstrations, she was 
never physically present at the riots (Kelly 61). Therefore, while she was the agent that threatened the colonial order, her contribution to the 1920 strikes was very different from the physical attacks against male colonial officials led by indentured women like Fulquhar, Rahiman, Rachael, Sonia, Mungri, Kalan, Ladu, Majullah, Hansraj, Dreemal, Hanki, Dwarka, Junkaom and Etwari. At a strike on February 23, The Fiji Times and Herald reported that this group of frenzied, kava-drinking, veiled women attacked colonial officials Constable Reay and Mr. Savage with doga sticks as they chanted 'hit, beat, kill' ('Indian Riot: Women the Cause' 9). In March 1920, these women were imprisoned by the colonial government for these radical confrontations and Jaikumari was deported to India for instigating the cost of living strike and organising women into protest groups (Colonial Secretary's Office, 'The Select Committee', MS No.2352). What is particularly noteworthy here is the way the fight against economic oppression was inseparable from the battle against colonialism and patriarchy.

At the same time, another group of women across the seas was deeply disturbed by the plight of their sisters in Fiji. On 25 August 1920, The Sydney Morning Herald reported: 'Recent official communications from Fiji reveal in interesting detail the unostentatious and humanitarian efforts, not widely known, of a band of Australian and New Zealand women to improve the moral and social conditions of Indian women in Fiji' ('Indian Women: Social Conditions in Fiji' 9). It is this interesting detail that I wish to recover in this article - this minor historical account ${ }^{1}$ of how Australian and New Zealand women collaborated with middle-class women from India to form the Australasian Committee of Inquiry into the Social and Moral Conditions of Indian Women in Fiji on 27 May 1918. Set against a backdrop of patriarchal morality that intersected with discourses of colonialism, imperialism, Christianity and Indian nationalism, it is evident that this Committee fostered a homogenous notion of universal sisterhood. Although parallel resistances were mounted by indentured women as they agitated for their basic human rights, such as access to food, within the context of colonialism and indenture, a convergence did not take place between the trajectories of women's resistances until Australasian women began to lobby for the attainment of basic human rights for indentured women, for example, access to adequate health care and facilities.

The activism of the Australasian Committee of Inquiry may be categorised into two broad phases. During the first phase (1916-1918), the Committee demonstrated a preoccupation with cultivating and reinforcing stereotypical feminine virtues like purity and chastity. The focus of this phase was on a

1 The term minor history was coined by Sudesh Mishra in his keynote address delivered at the International Scientific Conference in Mauritius on 5 December, 2011. See "“Bending Closer to the Ground": Girmit as Minor History' in this issue of AHR. 
male-centred notion of traditional morality, in particular, an endorsement of the patriarchally-constructed view that men and women's morality should be assessed differently. When the Committee argued that women should be virtuous, pure and chaste, they reinforced 'ethical double standards' (Mill 10) imposed by patriarchal society. However, as the Committee of Inquiry began to lobby for health and reproductive rights for indentured women during the second phase (1918-1922), they also assisted women to fulfill other interconnected fundamental human rights, such as the right to employment. This was a critical turning point for the Committee because the act of caring for women's bodies was a definite step towards women's empowerment. I will begin with a discussion of the first phase.

\section{Patriarchal Morality (1916-1918)}

\section{Vices and Virtues}

Indentured women featured in colonial exchanges, often in passing as a footnote or afterthought, and other times as objects of much deliberation, especially when they transgressed the neatly demarcated boundaries of femininity. The latter is illustrated in 'A Report on Indentured Labour in Fiji' written by representatives of the Indian Government Reverend Charles Freer Andrews and William Pearson in 1916. I cite this report here because it triggered a series of events that led to the formation of the Committee of Inquiry. As it broached the subject of women's morality, or rather their alleged immorality, it invoked anger and concern among Australasian women and incited them to take action. Like Andrews and Pearson, they were gravely concerned that the practice of disproportionately recruiting forty women for every one hundred men was the primary cause of a 'strange, unaccountable epidemic of vice' (Andrews and Pearson 27) in the coolie lines. At this point, the eroding moral status of the so-called 'simple, ignorant, coolie woman' (Andrews and Pearson 11) becomes a central issue of contention. In the report, she is juxtaposed against the middleclass Indian woman and a series of binary oppositions emerge. The middle-class Indian woman is identified with virtues of chastity, honour (izzat), discipline and devotion, while descriptions of indentured women pivot around vices like promiscuity. In this sense, the middle-class Indian woman becomes the benchmark for assessing morality among indentured women in Fiji. Another cause of anxiety for Andrews and Pearson, and this worry was also shared by Australasian women, was the indentured woman's inability to fulfil the most sacred duty of an Indian woman which was 'to cook her husband's food and look after his home' (10). Essentialist images of women as mothers and wives are naturalized throughout the report. 


\section{Sisterhood and Honour}

Missionary Florence Garnham notes that Andrews and Pearson's 1916 Report 'made a great impression on the Indian people' (10) including the Viceroy, who announced on 20 March 1916, that the indentured system would be abolished at the earliest date. When the Indian public learnt in January 1917 that the system would not be abolished for five more years, prominent middle-class Indian women took to the streets and began pleading before 'immense audiences for the honour of their sisters' in Fiji ( 'Ladies Urge Cancellation of Indentures' 13; see also Garnham 12). Honour became a metaphor for sisterhood. As Indian women fought fervently for this highly regarded virtue, caste and other differences were promptly set aside. This was a critical moment for Indian women given the strict social stratification of Indian society into Brahman (priest), Kshatriya (ruler, warrior and landowner), Vaishya (merchants), Shudra (artisans, agriculturalists) and Harijan (untouchable) castes (Singh 11).

However, there were other specific instances, where Indian women used their caste and status in society to raise a public outcry about the exploitation and abuse of Indian women in Fiji. In 1918, for example, Indian women met at the Vanity Vishram Hall in Bombay to urge the Government of India to prohibit the continuation of the indenture system. Chair of the meeting Lady Pherozeshah Mehta stressed that the indenture system was 'fraught with hideous immorality ... under which the honour of a woman was not safe' ( 'Ladies Urge Cancellation of Indentures' 13). Mrs. Jaijee Petit also led a deputation of women to the Viceroy to plead for an end to the recruiting process (Andrews 20). If we accept feminist scholar Uma Narayan's argument that Indian nationalism 'associated women with the preservation of Indian traditions, culture and spirituality' (133) then it is possible to suggest that the sexual exploitation of indentured women was chosen as a central focus by nationalist patriarchies to emphasise the moral status of women associated with monogamous marriages and motherhood. Thus, as Indian women campaigned for the honour of their sisters in Fiji, they simultaneously 'colluded in the patriarchal regulation of female sexuality' (Welchman and Hossain xi).Of course, the counter-argument is that middleclass Indian women, who were economically privileged and had the leisure time to engage in such affairs, consciously employed patriarchal codes, for example, the honour/shame binary, to draw public attention to the exploitation of women labourers in Fiji, and in doing so, deconstructed patriarchal structures that oppressed other women. In this way, middle-class Indian women sometimes relied on acts of mimicry to camouflage their resistances.

In 1918, this internal bond of sisterhood among middle-class Indian women was extended to include Australian and New Zealand women. The Sydney Morning Herald draws attention to this point of collaboration: 'There is in India an active and large society of high-class native women. Learning of conditions of the 
Indian women in Fiji, but recognizing that they were handicapped geographically in any effective steps to improve matters for them, they appealed, and not in vain, to the women of Australia and New Zealand, because of their proximity to Fiji, to take up with the authorities the case of Indian women there' ('Indian Women, Social Conditions in Fiji' 9). Their plea for assistance was accepted by Australian and New Zealand women who, after reading Andrews and Pearson's report, were also anxious to conduct their own investigation into the matter of morality in Fiji. As a result of these collaborative efforts, the Committee of Inquiry was born.

\section{Purity, Chastity and the Angel in the House}

Organisations affiliated to the Committee of Inquiry with international links included the Australasian Board of Missions, the Young Women's Christian Association and the Australasian League of Honour for Women and Girls. Some of the Australian-based organisations involved included the National Council of Women in states throughout Australia, the Church of England Mother's Union, the Child Study Association, the London Missionary Society Women's Auxiliary, the Women's Christian Temperance Association, the Women's Reform League, the Women's Peace Army, the Association of Women Workers, the Baptist Women's Missionary Association Auxiliary, the Church Missionary Society, the Methodist Mission Auxiliary, the Women's Service Guild of Western Australia and the Society to Combat Social Evil ('Indian Women, Social Conditions in Fiji' 9). The only New Zealand association affiliated to the Committee of Inquiry was the Women's Christian Temperance Union. On the whole, many of these organisations were driven by the need to help the enslaved or colonised 'Other'. This imperialist agenda was strengthened by a Christian ethos of love and patriarchal constructions of femininity and female sexuality. Underlying this union between colonial, imperial, Christian and patriarchal ideologies are virtues of faith, hope, love, devotion, humility, chastity, purity and honour. For example, the Australasian Board of Missions, formed in Sydney in 1850, strove to convert indigenous Australians to the Anglican faith (Australian Women's Register). Comparatively, the Australasian League of Honour for Women and Girls, an offshoot of the British League of Honour, was established in 1915 to promote the welfare and development of young women and girls. In their week of humiliation and prayer, members of the league were encouraged to strive for 'a higher ideal and standard of purity in every department of life' ('Australasian League of Honour' 3). The Women's Christian Temperance Union reiterated a similar view of morality as it worked 'for God, for home and for humanity' (2). This Union was established in New Zealand in 1855 when Mrs. Leavitt arrived from the United States bearing with her a petition signed by women from all over the world to introduce the prohibition of alcohol because of its alleged effects 
on family life (Women's Christian Temperance Movement 2). Even organisations with a broader social justice agenda like the National Council of Women stressed virtues of sympathy and humility in the 1900s.

Ideals of domesticity, honour and chastity, foundational to Australasian women's transnational sisterhood, are perhaps best illustrated through the Victorian notion of the 'Angel in the House'. This devoted, submissive wife was expected to be 'passive and powerless, meek, charming, graceful, sympathetic, self-sacrificing, pious and above all - pure' (Stansell 466). She existed within the woman's sphere where she was required to carry out all duties in the home as well as engage in religious and charitable activities. As organisations affiliated to the Committee of Inquiry set out to nurture the Angel in the House, they placed a significant emphasis on cultivating personal disposition and character. In fact, it can be said that they reiterated the Aristotelian view that 'good and right behaviour emanates from within a person' (Preston 45). The Committee's quest to foster virtuous ideals involved combating social evil as well. For example, its members played an active role in the Women's Convention on Social Evil, arranged by the Women's Political Association on 6 May 1916 in Melbourne Australia. The convention met to oppose a State Health Bill to regulate prostitution. Its aim was to produce a 'happy and truly moral community' (Women's Political Association).

\section{Florence Garnham: Revisiting the Angel in the House}

When the Committee of Inquiry was established in 1918, its first major undertaking was to dispatch Florence Garnham of the London Missionary Society in Calcutta to 'study the conditions of Indian life from a moral standpoint' (Garnham 4). Garnham, who was also a member of the committee, carried out investigations in Viti Levu from June 4 to August 26, 1918, and produced a thirty-page document titled: 'A Report on the Social and Moral Conditions of Indians in Fiji'. The recommendations proposed in her report were relayed to the Governor of Fiji at the time, Sir Ernest Sweet-Escott, in a letter written by the President of the Committee, Winifred Scott Fletcher, on 3 April 1919. It stated: 'The Committee of Inquiry into the social and moral conditions of Indian women in Fiji comprised of leading women's Philanthropic Societies throughout Australasia earnestly and respectfully begs that the following reforms suggested in the Report of Miss Garnham shall receive the consideration of your government' ('Committee of Inquiry' Letter). In response to this letter, the Governor appointed a Select Committee in 1919 to examine the report. The Select Committee described Garnham's Report as 'temperate and reasonable' (Colonial Secretary's Office, Minutes 2630/19) and proceeded to work with the Committee of Inquiry to implement some of the proposed recommendations. 
Garnham's Report was germinal because it functioned as an informal mandate for the Committee of Inquiry and some fourteen years were spent advancing the recommendations proposed in it through internal dialogues with the Colonial Government. On the one hand, Garnham echoed propositions made by Andrews and Pearson in 1916. Amongst these were suggestions to adjust the sex ratio, promote sanctity in marriages, foster purity in the home, and free women from plantation work so they could tend to duties in the domestic sphere and care for their children. The latter reinforces the separation of public and private spheres according to gendered norms. It emphasises that women should be relegated to the private or the woman's sphere and excluded from the public sphere. Binary oppositions of honour/shame and chastity/prostitution also resurface as Garnham affirmed: 'It was impossible for a woman to preserve her chastity in the coolie lines' (6). While the Select Committee felt that little could be done to adjust the sex ratios, it supported Garnham's recommendation to appoint women doctors and nurses and provide education for women and girls (Colonial Secretary's Office, 'The Select Committee Minutes', MS No.1157/19). These proposed reforms to health and education were vital in narrowing the gap between Australasian women's intentions to improve the lives of indentured women and the basic needs of this group of women in light of the realities of their lived experiences. When these trajectories converged, the Committee's efforts begin to shift towards the second phase of women's organisation.

\section{Health Reforms and Women's Empowerment (1918-1922)}

International health reforms from the 1880s to the mid 1920s intersected with the broader objectives of the 'purity movement' or the 'social purity crusade' (Engs xv) which was largely concerned with advancing a 'single-standard of sexuality', sharing knowledge on child-rearing practices and promoting antiprostitution (Engs $\mathrm{xv}$ ). In this sense, religion was an underlying factor behind the intersection between women's morality and health, particularly as it advanced aspects of social purity and cleanliness in relation to the female body. However, it is equally important to note that health is 'one of the vital indicators reflecting quality of human life' (National Human Rights Commission). My main argument here is that the provision of information on pre-natal and post-natal care, sexually transmitted diseases and family planning were vital to improving the quality of life for indentured women. Indentured women also affirmed the need for these vital services. Moreover, given that health rights are intricately related to other rights like food, housing, employment, education and so 
forth, the Committee of Inquiry also contributed to the attainment of some of these rights as well. For instance, it played a critical role in pressurising the government and the community to educate Indian girls.

The health reforms proposed by Garnham were based on conversations held with indentured women and men in colonial Fiji. During these conversations, Garnham uncovered that in addition to the high costs incurred while in plantation hospitals (2/- a day), the male respondents she spoke to said that they objected to their women being treated by other men, particularly when they were not qualified doctors (Garnham 25). When these observations were relayed to the Committee of Inquiry, it proposed that member Dr. Kate Knowles formulate a request to the Fiji Government to urge for an improvement to medical facilities. Some of the recommendations included: the establishment of government dispensaries where Indians could receive free outpatient treatment, the employment of four Indian girls as obstetric pupils and the appointment of a female Junior Medical Officer (Legislative Council Paper No. 46). The Fiji Government approved these recommendations and invited the Committee to find an appropriate candidate for the position of Junior Medical Officer. The criteria it offered was that: 'She should come from India or have had Indian experience' (Legislative Council Paper No. 46). The Committee promptly utilised its transnational networks as it placed advertisements in medical journals throughout Australia, India and Great Britain. Care was taken to select a candidate who could withstand the working and living conditions in colonial Fiji and more importantly, who could speak Hindustani. After an extensive search, the Committee chose Dr. Mildred Staley, a graduate of London University and daughter of Reverend Thomas Staley. The Sydney Morning Herald stated that: 'She was selected because of her extensive experience of life in India and her work throughout the war with the French Red Cross and the Serbian Army' ('Dr. Mildred Staley' 7). Although Dr. Staley arrived in Fiji on January 1, 1921, one year after all remaining indentures were cancelled, the appalling conditions associated with indenture continued and so did the struggle for health reforms. From 1921-1922, Dr. Staley played a critical role in attending to Indian women's health and reproductive rights and training Indian women as mid-wives.

When the Fiji Government announced that it was compelled to dispense of the services of Dr. Staley in 1922, it was indentured women in Fiji who first collectively and publically opposed this decision. They expressed alarm 'at the prospect of losing the attentions of a doctor of their own sex' ( 'Women Petition Governor' 14) and led a deputation to the Governor, Sir Cecil Rodwell. In a petition presented to the Governor, they stated that: 'It was their prayer that the excellent provision for their medical needs might be continued and even increased' ( 'Women Petition Governor' 14). What did this prayer mean to indentured women? In the context of indenture, the female body was often 
physically and/or sexually violated by men in public and private spheres. These sorts of violations often resulted in humiliation, degradation and the culmination of feelings of insecurity and fear among women. Therefore, when Dr. Staley developed a bond of trust with indentured women, she created a safe space to care for the vulnerable female body. This bond was important because it directly intersected with the daily needs and rights of indentured women in Fiji. In this instance, class, ethnic and religious differences between indentured women workers and middle-class Australasian women did not act as barriers to their collective solidarity.

Not surprisingly, when the Fiji Government explained that Dr. Staley was retrenched due to 'financial stringency', Australasian women joined indentured women in their protests. The Sydney Morning Herald captures this global outcry by women: 'Although occurring in a remote corner such as Fiji, it has become an international matter, for not only have the Australasian Committee cabled to the Fijian Government and Colonial Office, urging the continuance of this appointment on the grounds of its absolute necessity, but representations have been made to the Colonial Office' ('Women Petition Governor' 4). Although this verdict was not retracted, the Committee of Inquiry continued to lobby for the health rights of indentured women until a decision was made to disband the committee in 1932. Other associations, such as the Methodist Missionary Society of Australasia under the supervision of Nurse Lawrence, were conducting excellent medical work in Fiji. The Committee of Inquiry acknowledged these efforts as it handed over its existing funds to this Society in 1932 to continue the work it had started in the area of women's health in the 1920s ( 'Indian Women: Committee Disbanded' 3). By then, the basic foundation for women's health rights had already been established.

\section{Recovering Women's Lost Voices}

Since the 1970s, feminist historians and ethnographers have embarked on an often converging journey to restore women to history and to 'recover women's lost voices' (see Waaldijk and Visweswaran). This article has attempted to contribute to these fields of study by documenting the 'humanitarian efforts' ( 'Indian Women, Social Conditions in Fiji') of the Australasian Committee of Inquiry into the Social and Moral Conditions of Indentured Women in Fiji. While the article has been critical of the Committee's efforts to transplant values that reinforced patriarchal morality as reflected in colonial, imperial and Indian nationalist discourses, it has simultaneously celebrated its struggle to improve the quality of life for indentured women in Fiji through health reforms. The point I wish to highlight here is that when the efforts of this transnational network of Australasian women directly intersected with the daily needs of indentured 
women and they acknowledged this, a critical transcultural exchange between women began in 1922. This dialogue was fueled by intersections with global, regional, and national networks and historical circumstances.

Margaret Mishra received her PhD from Monash University in Melbourne and teaches ethics and governance at the University of the South Pacific in Fiji. Her research interests currently focus on feminisms, indenture and ethics.

\section{Works Cited}

Andrews, Charles and William Pearson. 'Report on Indentured Labour in Fiji.' Unofficial Report for the Indian Government, 1916.

Ashcroft, Bill, Gareth Griffiths and Helen Tiffin. 'Introduction: Feminism and Postcolonialism.' The Postcolonial Studies Reader. London: Routledge, 1995. 249-250.

'Australasian League of Honour.' The Mail, 18 May 1918: 3.

Australian Women's Register. 'The Women's Auxiliary to the Australian Board of Mission.' 2010. <http://www.womenaustralia.info/biogs/AWE0757b. htm $>$. Accessed 10 November 2010

Colonial Secretary's Office. 'Committee of Inquiry into the Social and Moral Conditions of Indian Women in Fiji.' Suva: The National Archives, No. 2630; 1919.

Colonial Secretary's Office. 'The Select Committee. Minutes.' Suva: The National Archives, No. 1157/19; 1920.

Colonial Secretary's Office. 'The Select Committee.' Suva: The National Archives, No. 2352; 1920.

'Commission to Enquire into Cost of Living.' Fiji Times and Herald, 3 February 1920: 7 .

Committee of Inquiry. Letter to Governor of Fiji, Sir Ernest Sweet-Escott. 3 April 1919. Fiji National Archives.

‘Dr. Mildred Staley: Medical Officer.' Sydney Morning Herald, 23 March 1921: 7.

Engs, Ruth. The Progressive Era's Health Reform Movement: A Historical Dictionary. USA: Greenwood Publishing Company, 2003. 
Garnham, Florence. A Report on the Social and Moral Conditions of Indentured Women in Fiji. Being the Outcome of an Investigation set on Foot by Combined Women's Organisations of Australasia. Sydney: Kingston Press, 1918.

'Indian Riot: Women the Cause.' Fiji Times and Herald, 25 February 1920: 9.

'Indian Women, Social Conditions in Fiji: Australian Women's Efforts.' Sydney Morning Herald, 25 August 1920: 9.

Kelly, John. 'Jaikumari.' Bittersweet. Ed. Brij Lal. Canberra: Pandanus Books, 2004. 61 .

'Ladies Urge Cancellation of Indentures.' Northern Territory Times and Gazette, 8 November 1919: 13.

Lal, Brij. Broken Waves: A History of the Fiji Islands in the Twentieth Century. Honolulu: U of Hawaii P, 1992.

Lateef, Shireen. 'Indo-Fijian Women: past and present.' Manushi: A Journal About Women and Society 39 (1987): 2-5.

Legislative Council Papers. Journal of the Legislative Council. Suva: The Fiji National Archives, No. 46.

Mill, J.S. 'The Subjection of Women.' 1970. <http://www2.hn.psu.edu/ faculty/jmanis/jsmill/JS-Mill-Subjection-of-Women6x9.pdf $>$. Accessed 29 November 2011.

Mishra, Margaret. 'The Emergence of Feminism in Fiji.' Women's History Review 17.1 (2008): 39-56.

Naidu, Vijay. The Violence of Indenture in Fiji. Suva: The University of the South Pacific, 1980.

Narayan, Uma. 'Colonialism and Its Others: Considerations on Rights and Care Discourses.' Hypatia 10.2 (1995): 133-140.

National Human Rights Commission. Webpage. <http://nhrc.nic.in/ publications/Womens.pdf $>$. Accessed 14 November 2011.

Preston, Noel. Understanding Ethics. Sydney: The Federation Press, 2007.

Shameem, Shiasta. 'Sugar and Spice: accumulation and the labour of Indian women in Fiji in 1879-1930.' Doctoral Dissertation: University of Waikato, 1990.

Singh, Ekta. Caste System in India: A Historical Perspective. Delhi: Kalpaz Publications, 2009. 
Stansell, Christine. 'Revisiting the Angel in the House.' The New England Quarterly 60.3 (1987): 466-483.

Visweswaran, Kamla. Fictions of Feminist Ethnography. Minneapolis: U of Minnesota P, 1994.

Waaldijk, Berteke. 'Of Stories and Sources: Feminist History.' Women's Studies and Culture: A Feminist Introduction. Ed. Rosemarie Buikema and Anneke Smelik. London: Zed Books, 1993. 14-25.

Welchman, Lynn and Sara Hossain. 'Preface.' Honour: Crimes, Paradigms, and Violence Against Women. London: Zed Books, 2005.

Women's Christian Temperance Union. Homepage. <http://www.wctu.org/>. Accessed 15 November 2011.

'Women's Committee Disbanded.' Sydney Morning Herald, 9 February 1922: 3.

'Women Petition Governor.' Sydney Morning Herald, 11 November 1922: 14.

Women's Political Association. 'Social Evil Women's Convention-Proceedings.' Melbourne: Australia. 6 May 1916. 